\title{
MATERIAL AND LIVING CONDITIONS OF THE JEWISH PEOPLE IN GHETTOS IN THE RZESZÓW POVIAT DURING GERMAN OCCUPATION
}

\begin{abstract}
The aim of this paper is to present the situation of Jewish people living in ghettos in the Rzeszów poviat during the German occupation, highlighting the key issues. First, the paper focuses on living and sanitary conditions in the ghettos, which included poor conditions and no access to basic means of hygiene, creating a significant impact on the sanitary situation and negatively affecting the health of ghetto inhabitants. The flats were cramped, with sometimes over a dozen people living in one room. Second, the paper focuses on food, with short food supplies supplemented by aid organizations and illegal trade. It is argued that increasing poverty mainly affected those who were poor before the war with little financial resources. Third, the paper deals with diseases and the attempts to treat them. The fight against disease and epidemics was one of the greatest challenges faced in the ghettos. Treatment was difficult due to a lack of basic medications and medical resources with little professional help. This article is based on archival documents, other publications on this subject, and reports from Holocaust survivors.
\end{abstract}

Keywords: Jews, Holocaust, ghetto, German occupation, Rzeszów poviat.

\section{INTRODUCTION}

Studies on the period of the Holocaust in Poland are relatively well reported by many outstanding researchers; however, many gaps, especially concerning regional history, still remain that should be filled. These gaps are partly filled by a study prepared by Elżbieta Rączy, Zagłada Żydów w dystrykcie krakowskim, and many information on the fate of Jews during the German occupation can also be found in the works of Artur Eisenbach (Eisenbach, 1961) and Stanisław Zabierowski (Zabierowski, 1975). Another valuable source of information is the publication Losy Żydów Rzeszowskich 1939-1944 by Franciszek Kotula, a regionalist and ethnographer. Information about Jews during the Holocaust can also be found in numerous articles, usually referring to the whole Kraków district, but in some cases to the history of Jews living in selected areas of the Rzeszów poviat, as, for example, in articles by Stanisław Poradowski Zagłada Żydów Rzeszowskich, describing their situation in Rzeszów during the occupation. Foreign publications are also worth noting, as they are valuable source of information about fates of Jews from the Rzeszów poviat, for example, publications of landsmanshaft from Rzeszów or Kolbuszowa,

\footnotetext{
${ }^{1}$ Ewa Trojanowska, MA, University of Rzeszów, al. Tadeusza Rejtana 16C, 35-310 Rzeszów, Rzeszów; ewatrojanowska.ur@gmail.com. ORCID: 0000-0003-4904-3194.
} 
the so-called Memorial Book. This article is also based on archival documents, as well as reports and recollections of Holocaust survivors.

Before the outbreak of the Second World War, the Rzeszów poviat was the most western part of the Lviv voivodeship. It included five towns: Rzeszów as the capital of the poviat, Błażowa, Głogów, Strzyżów, and Tyczyn, as well as eleven collective communes². According to the population census conducted in 1931, 185,106 thousand people lived in its territory, of whom 145, 039 thousand lived in rural areas ${ }^{3}$. The Rzeszów poviat was inhabited by Poles, Jews, and a small number of Ukrainians. First information about Jews living in the poviat come from the beginning of the $16^{\text {th }}$ century from Rzeszów; in other towns the period of Jewish settlement is dated to the beginning of the 17th century. This was possibly caused by fast and dynamic development of the town and more extensive opportunities for the trade. According to the population census conducted in 1931, in the poviat Jews represented over $36 \%$ of inhabitants of towns, while only $2.9 \%$ of people living in rural areas (Wierzbieniec, 2013). The number of people of the Jewish faith started to grow fast both in the voivodeship and in the Rzeszów poviat, which was best visible in Rzeszów, where 12,841 Jews lived in 1937 (Wójcik, 1998), while before the outbreak of the Second World War that number grew to ca. 14 thousand. However, the growing and developing Jewish community could also be observed in places other than Rzeszów, for example, in Błażowa, where Jews were an active social group owning the majority of commercial companies handling the maintenance of roads in the Rzeszów poviat (Wnęk, 1995). Despite many well-prospering Jewish enterprises, Jews were a diversified social group, from pedlars and small shop-owners whose income barely supported their existence, to a scarce group of entrepreneurs, merchants and intelligentsia, who actively contributed to assistance for the poorest groups by supporting various initiatives, including cultural and educational, thus being an important part of the society, which quickly made its mark in town and poviat structures.

First days after the outbreak of the war and the entrance of the Wehrmacht to towns of the Rzeszów poviat did not bring great changes, with shops and enterprises operating normally. However, the changes occurred fast, and soon normal functioning of citizens, particularly Jews, became limited significantly.

Poland was divided between the Soviet and the German occupiers. Western, southwestern and northern areas were annexed to the territory of the Third Reich. From the remaining areas, not annexed to the German state, the General Government was formed, subdivided into four districts: Krakow, Lublin, Radom, and Warsaw (Rączy, 2014). Those districts were further sub-divided into urban and rural counties.

\section{LIVING AND SANITARY CONDITIONS}

Already at the beginning of formation of German administrations, Jews were forbidden to move and to dispose of their property. A German regulation published on September 6, 1939 ordered marking of all Jewish buildings in the occupied territory. In Rzeszów, and in

\footnotetext{
${ }^{2}$ In 1934, the Rzeszów poviat consisted of the following collective communes: Głogów, Trzebownisko, Świlcza, Racławówka, Słocina, Tyczyn, Hyżne, Błażowa, Błażowa, Czudec, Strzyżów, Niebylec, Journal of Laws from 1934, No. 64, item 552.

${ }^{3}$ Drugi powszechny spis ludność z dn. 9 XII 1931 r. Mieszkania Gospodarstwa domowe. Ludność. Stosunki zawodowe. Województwo lwowskie bez miasta Lwowa, "Statystyka Polski”, Seria C, z. 68, GUS, Warszawa 1933.
} 
the entire poviat, this law came into force on September 13. Buildings and places of religious worship were devastated, many Jewish graveyards throughout the Rzeszów poviat were completely destroyed, and gravestones were used, for example, to pave roads.

On December 1, 1939, with a regulation of Hans Frank, all Jews staying at the territory of the General Government, who were 10 years of age and older, were obliged to wear armbands with the Star of David on their right forearm. This symbolic marking was intended to isolate the Jewish community, helped to capture Jews and subject them to forced labour, and helped Germans in enforcement of anti-Jewish regulations, such as a ban to walk in certain streets and parks, travel by train, conduct trading activities etc.

Operating structures of Jewish communes changed in relation to their pre-war form. The newly created structures included a housing department, later transformed into a department of displaced people, a provisions department distributing food products, a labour department responsible for directing to various types of forced labour and for providing assistance to Jews in labour camps. A school council and a legal department were also established. As a large number of displaced people arrived to Rzeszów, under the order of the German authorities, the Population Registration Office was established, located in the Judenrat building, a pre-war building of the Jewish Commune (Poradowski, 1983).

In the first period of the war, the housing situation of the Jewish people did not change much, they could still live in their houses, and only some of them were expelled and lost their flats. The greatest changes in the housing situation occurred when refugees and displaced people arrived. They were sent to new places of living with only a small amount of things, so on arrival to the designated town they did not own any resources, clothes and goods that could be sold or exchanged for food. As no places were available, they slept on wooden bunks; not only there were no beds for them, but also no bedlinen and blankets ${ }^{4}$.

Under the regulation issued by the Rzeszów staroste on December 1, 1941, creation of Jewish districts was ordered in the territory of the whole Kreis Reichshof.

Due to increasing poverty and hunger, many Jews were in difficult situation and needed help provided by Judenrat and other Jewish charity and aid institutions. New groups of displaced people arriving to Rzeszów aggravated the already bad housing situation. Small flats housed even several families, people lived not only in tiny rooms, but also in corridors and stairwells, just to have some roof over their heads. In Głogów Małopolski, Jews had at their disposal about 20 houses, and even up to 50 people stayed in each of them (Borkowski, 2016). It was practically impossible to maintain basic sanitary conditions. Despite submitted complaints about the living conditions in the ghettos, nobody paid attention to them, and the situation only continued to deteriorate.

As Franciszek Kotula recalls, Jewish houses were stripped of everything that had any value and could improve the standard of living in any way:

Eventually, the main objective was exposed: to rob Jews. Thus, policemen and gendarmes entered Jewish houses, from which money, jewellery, textiles, furs, bed linen, and bedclothes themselves were mercilessly taken away. The booty was taken away by cartloads (Kotula, 2019).

\footnotetext{
${ }^{4}$ Archiwum Żydowskiego Instytutu Historycznego, Żydowska Samopomoc Społeczna (Jüdische Soziale Selbsthilfe Jüdisches Hilfskomitee). 1940-1942 [1944], No. 211 (further on: 211), ref. 223.
} 
The houses lacked everything - bed linen, blankets, water, and basic means of hygiene, as well as space and silence. Similar conditions prevailed in all ghettos established throughout the country. Refugees were housed in every available residential building, synagogues, houses of prayer, barracks, and hostels (Poradowski, 1997). The Rzeszów ghetto, of the area below 10 ha, which at the beginning of the war was inhabited by 12,000 Jews, and twice as many people from the middle of 1942, became overpopulated due to arriving displaced people, for whom there was no place (Rączy, 2014).

Table 1. Ghettos of the Rzeszów poviate ${ }^{5}$

\begin{tabular}{|l|c|c|}
\hline \multicolumn{1}{|c|}{ Location } & $\begin{array}{c}\text { Date of establishing and } \\
\text { of closing the ghetto }\end{array}$ & Number of imprisoned people \\
\hline Błażowa & $1941 / 1942-$ June 26, 1942 & 993 \\
\hline Czudec & $1941 / 1942-$ June 1942 & 500 \\
\hline Głogów Małopolski & February 1942 - June 1942 & 1344 \\
\hline Jawornik Polski & February 1942 - June 1942 & 450 \\
\hline Kolbuszowa & June 13, 1941 - June 24, 1942 & 2,500 \\
\hline Niebylec & $1941 / 1942-$ June 25, 1942 & 450 \\
\hline Rzeszów & December 1941 - September 1943 & 12,765 \\
\hline Sokołów Małopolski & June 1942 - July 1942 & 3,082 \\
\hline Strzyżów & February 1942 - June 1942 & $*$ \\
\hline Tyczyn & March 1942 - June 1942 & $*$ \\
\hline
\end{tabular}

*No data

Source: (Pilichowski, red. (1979); The United States Holocaust Memorial Museum Encyclopedia of Camps and Ghettos, 1933-1945. Vol. 2...; The Yad Vashem Encyclopedia of the Ghettos During the Holocaust. Vol. 1 (A-M)...; Archiwum Żydowskiego Instytutu Historycznego, Żydowska Samopomoc Społeczna (Jüdische Soziale Selbsthilfe Jüdisches Hilfskomitee). 1940-1942 [1944]).

The situation was aggravated even further when ghettos in the neighbourhood area were liquidated, and their residents moved to Rzeszów. The conditions in the ghetto were very bad, and no access to basic means of hygiene had a significant effect on the already bad sanitary situation, which, in turn, negatively affected health of ghetto inhabitants. As George Lucius Salton, who was resettled from Tyczyn with his family, recalls, they were very lucky because they were offered accommodation in a house of their acquaintance. The flat, just as the whole house in which they lived, was cramped; six people lived in one small room, and this number is still not high, taking into account the fact that in some cases over ten people lived in one room; and having a shared kitchen and a bathroom was a huge luxury in the generally prevailing conditions (Lucius Salton, 2004). As not everybody had access

\footnotetext{
${ }^{5}$ Similarly as in the case of other ghettos, it is difficult to determine precisely how many Jews were in ghettos in the Rzeszów poviate. In the article their locations were assumed after Encyclopedia of the Camps and Ghettos. The problem in estimation of their number results from lack of data and from frequently contradictory information that makes the evaluation impossible, as noted by Elżbieta Rączy (Zagłada Żydów w...). Such example is Jawornik Polski, which was listed amongst the ghetto locations, yet there are no documents to confirm this, and one of the survivors, Sara Langsam, says that there was no closed ghetto, and everybody lived in their houses until its liquidation (AYV, 0.3, ref. 1816), and the situation was also similar in, e.g., Tyczyn.
} 
to common bathhouses, and the access to water itself was limited, people washed rarely, and a bath was a luxury (Herzlog, 2004). In one of the neighbouring towns, a large tub with water was placed in the street, but when Germans saw Jews washing themselves, they made them an object of mockery, ordering all of them to get into the tub with water and wash themselves in their clothes (Borkowski, 2016). Wolf Finkelman, who was then in the Głogow ghetto, recalls that although there was a mikveh in the town, the Germans did not allow the Jews to use it often, the main reason was that they themselves often used it $^{6}$. Not only the lack of possibility to bath, but also the lack of soap was a problem, because its assignment was small taking into account the number of people in the ghettos ${ }^{7}$.

The worst situation was in winter, when flats were dirty and sooty from smoke from stoves. Windowpanes were coated by a layer of ice so thick that not much daylight could penetrate into rooms. Anything flammable was burned in the stoves, for example, boards were torn from the floors. In winter, to get warmer, everybody slept close to each other, and floors were strewn with straw (Oster, 2013). In Rzeszow The situation was dramatic especially in the west ghetto where the people didn't have jobs or work and they dying on the streets.

The situation was hard not only for displaced people, but also for Jews sheltered in hideouts in the whole ghetto. They were created in cellars or in specially prepared bunkers dug in the ground, which were wet and dark. The terrible conditions in them and the omnipresent hunger had a dramatic effect on emaciated residents of the ghettos.

\section{DISEASES AND ATTEMPTS AT TREATMENT}

Already during the first stage of the German occupation, an increased number of people using medical help could be noted. This was possibly caused by living conditions, and by violence used against Jews by Germans.

The deteriorating conditions in ghettos in the Rzeszów poviate negatively affected health of their residents. Many Jews required hospitalisation for diseases or in consequence of German brutality. At some ghettos Jews could count on medical care. In Kolbuszowa it was available from 1940, if a small clinic managed by doctor Anderman can be called as such. It was open only for two hours a day due to aid from AJDC and Judenrat, and was one of the most important institutions for the community (Salsitz, 1971).

Doctors working in ghettos had to face many problems such as epidemics, lice, and pests of all kind, like rodents that could carry various diseases. Besides terrible sanitary and hygiene conditions and malnutrition, overpopulation in the ghettos in the Rzeszów poviat was one of the main factors facilitating spreading of contagious diseases. Thus, it was necessary to initiate preventive actions; for example, quarantine was introduced in some buildings, attempts were also made to isolate patients from the remaining part of the community.

The access to doctors and medical assistance was limited, as data from 1940 show; only in some places there were doctors of Jewish origin, not mentioning hospitals or clinics. For

\footnotetext{
${ }^{6}$ Finkelman, W. Interview 12802. Segments 1. Visual History Archive, USC Shoah Foundation, 1996. Accessed 20 July 2020.

${ }^{7}$ Finkelman, W. Interview 12802. Segments 2. Visual History Archive, USC Shoah Foundation, 1996. Accessed 20 July 2020.
} 
example, such was the situation in Sokołów, where not even one doctor was available, and the mortality rate was at a level of $20 \%$, similarly as in other towns of the poviat ${ }^{8}$.

The number of doctors in each of towns of the poviate in which a ghetto was established was related to their size and a number of inhabitants before the war. The largest number of doctors of Jewish origin, $8^{9}$, stayed in Rzeszów; this possibly resulted from the fact that a Jewish hospital was located in this town ${ }^{10}$.

Outbreaks of epidemics and deteriorating health of the population, as well as emergence of numerous negative overlapping factors led to significant demographic changes. In first months of the occupation, a significant drop in the number of births together with a rise in the number of deaths could be noticed, and these disparities only increased with time.

The increased morbidity rate could already be noticed at the beginning of the occupation. Attempts were made to keep outbreaks of epidemic in secret, as it was known that if Germans had learnt about them, all patients would have been shot, as it was the case with patients from the labour camp in Rzeszów Aviation works, where all people suffering from typhoid were shot ${ }^{11}$. There were shortages of everything: medicines, vitamin formulations, even aspirin, in the ghettos. Nevertheless doctors strove to save all patients by any means (Wierzbieniec, 1995).

However, it should be mentioned that in Rzeszów itself, and in other ghettos in the Rzeszów poviat, hospitals and clinics were very poorly furnished because they were robbed of all valuable medical equipment, and only a very small portion of it was left. This situation also contributed to low treatment effectiveness.

Medicines delivered to the ghettos were distributed by the Jewish Social Self-Help (ŻSS), which sent and distributed medical resources in all districts. However, majority of medicines assigned to the Kraków district was delivered to facilities where hospitals were located. Quantities of medicines sent depended on a number of places for patients. With 38 beds for patients Rzeszów had the lowest allocation amongst hospitals in the district, while Kraków received the largest one ${ }^{12}$. Of course, medicines were also delivered to other places, such as Czudec; however, the quantity of provided essential medicines was insufficient for impoverished Jewish community, emaciated by deepening hunger ${ }^{13}$.

8 AŻIH, 211, ref. 21, Statistics of Jewish population in GG (number of people in individual towns, classified in categories, professions, number of doctors, sanitary status etc.).

9 AŻIH, 211, ref. 21.

10 The Jewish Hospital in Rzeszów was established in 1824. Since that date, its location changed many times, and in 1938 it was transferred to Leszczyńskiego street. The new hospital was created mainly with the financial assistance of Jewish immigrants in America. Before the war, it contained 30 beds, during the war their number increased to 38. At the end of 1939, by the order of German authorities it was moved to Matejki street. During the war, the following doctors used to work at the hospital: Dr Heller, Dr Tunis, Dr Bayer, Dr Kohn, Dr Ehrenreich, Dr Hoessl, Dr Hauptmann, Dr Zinnemann; (Zamoyski, 2004; Yad Vashem Archives, 03-Testimonies Department of the Yad Vashem Archives, ref. 734, Aleksander Heller report; AŻIH, 211, ref. 91, ŻSS Presidium Medicines distribution point. 1941).

${ }^{11}$ Yad Vashem Archives, 03-Testimonies Department of the Yad Vashem Archives, ref. 9364, Benjamin Bzhezhinski report.

12 AŻ̇H, 211 ref. 91.

13 AŻIH, 211 ref. 336 Correspondence of ŻSS Presidium with the Jewish Council and ŻSS Delegation in Czudec. 


\section{FOOD ISSUES}

It was not easy to help the Jewish community due to numerous restrictions, yet many people decided to provide aid, which was of an individual or organised nature. Organised aid was mainly provided by underground organisations, supplying food and medicines to ghettos, and issuing false documents. Jewish people in the ghetto in Kolbuszowa were helped by two members of Bataliony Chłopskie, who supplied food to the ghetto (Raczy, 2016). Similarly as other spheres of life, the material situation of Jewish population in the ghettos deteriorated, and in consequence of restrictions for Jewish people implemented by the German occupier, the increasing number of people had no job. The increasing poverty first affected the poorest sections of the society, who had no financial securities before the war, and had no money or goods to buy or to exchange for food. The assistance provided by Jewish organisations was a drop in the ocean of needs of the Jewish community in the Rzeszów poviat. During the first stage of the war, the aid was mainly provided to the displaced people, who had no possessions. Only to Niebylec, AJDC sent 500 zloty at the beginning of 1940, which was divided between the poorest inhabitants of the town, including people displaced from Kalisz and Łódź14. In some places, the situation was also improved by Jewish farmers; their number, however, was small. For example, in the whole Niebylec commune only 17 Jews were farmers ${ }^{15}$.

Decreasing supplies and money quickly affected the impoverished population, especially as prices of food started to rise drastically. In the middle of 1941 a loaf of bread cost 4 zloty, and a year later its price went up to 5 zloty. The deteriorating situation of the Jews was particularly visible when ghettos were closed (Raczy, 2014). Those who were able to keep some of their property started commercial activities on a large scale, although smuggling of goods from the Aryan side was associated with significant danger, also for Poles participating in this practice; especially in the light of the regulation of Dr Hans Frank, under which since September 15, 1940 Jews leaving the Jewish district without a permit were punished with the death penalty, similarly as Aryan population providing aid of any kind, supplying food, or trading with Jews.

Efforts were made to help children as much as possible, given that their situation was most difficult. One of the aid organisations operating in Rzeszów was Centos, with offices at Grodzisko street, and the Orphanage Committee, receiving regular subventions. However, similarly as in the case of other help, with time financial subventions started to decrease, and were insufficient to maintain the children and cover their basic needs. This situation forced an appeal for help to the community, which supported the Orphanage financially and materially, so it could provide further care for children (Poradowski, 1967). In Rzeszów, the pre-war action of feeding children was continued, in form of distributing a glass of milk and a piece of bread with marmalade to the poorest of them, three times a week.

As long as it was possible, all efforts were made to help the Jewish community in every possible way, so public kitchens started to be established. At the beginning, about 2400 meals were issued in Rzeszów alone; with time, this number dropped to 400 meals. This

\footnotetext{
${ }^{14}$ AŻIH, American Jewish Joint Distribution Committee. 1939-1941 (further 210), ref. 509, Correspondence between the Jewish Religious Community in Niebylec and AJDC in Kraków. Cash reports. Lists of people needing help.

15 AŻIH, 210 ref. 509.
} 
was probably caused by creation of the second kitchen, issuing 300 to 400 meals a day; however, it still does not add up to the initial number of issued meals.

Despite the visible poverty, in all ghettos the standard of living of the Jewish population varied, and it was even more noticeable when the ghettos were closed. A very small group of very rich people existed besides those very poor. It included higher officials of the communes $^{16}$, owners of enterprises, and people demonstrating strong entrepreneurial skills, who traded and smuggled goods from the Aryan side (Rączy, 2014). As Franciszek Kotula wrote, food trade flourished mainly because of Jews from the neighbouring towns, where it was easier to get a pass. Prices of food sold were enormous (Kotula, 2019). Traders sold everything: eggs, sausages, bread, even cooked broad bean. One glass of broad bean cost as much as 10 zloty (Oster, 2013).

Goods were smuggled not only to ghettos, but also to the Aryan side. It was always dangerous and required an ability to make useful contacts. Smuggling was frequently used by Jews residing in the ghettos, and by Poles. To smuggle goods, secret passages were constructed, to enter or to leave the ghetto:

there were Jews who could supply these goods. The cooperative in which I worked, maintained lively trading relationships with a certain Jewish woman who conducted this trade. And to purchase goods, I entered the ghetto a few times through such secret passage. Obviously, each such entrance to the ghetto had to be first arranged in detail with these Jews ${ }^{17}$.

This trade was something normal and everybody knew about it, including Germans, who sometimes turned a blind eye to this practice. Hilda Mandel recalls that after the resettlement from Strzyżów in 1941 to the Rzeszów ghetto, she was terrified thinking about food Shy says The black market had to go on and people gave everything what they have include lewellery ${ }^{18}$.

The pre-war poor and people without any practical craft were in the most difficult situation, like Nachum Sternhaim, a well-known Jewish composer. When he disposed of all his property, he could not maintain and provide food for himself and his family, and died of hunger in the Rzeszów ghetto, like many other Jews (Poradowski, 1967).

\section{FINAL CONCLUSIONS}

It must be remembered that the whole period of the German occupation was very difficult for the Jewish community. The material and living situation of Jews in ghettos was very bad due to lack of food and medicines, and bad living conditions combined with German restrictions and repressions made chances of survival very slim. As long as possible attempts to maintain components of pre-war life were made, and it was not easy due to the actions of the occupier, trying to take away from them the remnants of humanity through successive orders and bans. It is easy to see that the margin of ordinary life, was quickly

16 "The situation of Jews varies; some are doing quite well - and their number is relatively high, other live in terrible poverty (...) Only now you can see Jewish aristocrats from Judenrat and various officers " (Kotula).

17 AYV, 03, ref. 734, Walenty Sanecki report,

18 Mandel, H. Interview 28515. Segments 2. Visual History Archive, USC Shoah Foundation, 1997. Accessed 20 July 2020. 
decreasing especially after the ghettos had been closed. The situation was unbearable for many, especially when they were sent from small ghetto. To many, taking away the remnants of their property, or even the small amount of food taken for the road during deportations were not as horrible as extremely blood-thirsty and brutal behaviours of Germans. Nevertheless, all these actions equally contributed to depriving them of their normal existence.

The aid organizations operating in the ghettos and their management are worth noting, as they significantly influenced survival in ghettos. Organizing various collections to improve their operation or prolong the overall functioning of institutions gave a hope of survival, at least, during the first period of functioning of the ghettos. How we can see not only organizations in the ghettos played important function, but also smuggling often becoming the main food-earners. Emanuel Ringelblum (Ringelblum, 1988) as he notes smuggling protects from total starvation, but on the other hand by many it is used to enrich themselves in a starving society. However, as we can see from relaction of witnesses the problem of hunger was so big that every day on the street lying human bodies.

The number of Jews who survived the war was very low, according to the data, after the war one thousand people lived in the entire Rzeszów region, with the largest group of ca. 300 people living in Rzeszów (Basta, 1994).

\section{REFERENCES}

Armin Herzlog, H. (2005). And heaven shed no tears. Madison: University of Wisconsin Press. Basta, J. (1994). Mniejszości narodowościowe na Rzeszowszczyźnie 1945-1946. „Prace Historyczno-Archiwalne”, t. 2.

Borkowski, R. (2016). Głogów Małopolski w okresie II wojny światowej, Rzeszów: Podkarpacki Instytut Książki i Marketingu.

Drugi powszechny spis ludność z dn. 9 XII 1931 r. Mieszkania Gospodarstwa domowe. Ludność. Stosunki zawodowe. Województwo lwowskie bez miasta Lwowa, "Statystyka Polski”, Seria C, z. 68, GUS. Warszawa 1933.

Kotula, F. (2019). Losy Żydów rzeszowskich 1939-1944. Rzeszów: Fundacja Rzeszowskiego Ośrodka Archeologicznego: Oficyna Wydawnicza Zimowit.

Obozy hitlerowskie na ziemiach polskich 1939-1945. Informator encyklopedyczny (1979), red. Cz. Pilichowski. Warszawa: Państwowe Wydawnictwo Naukowe.

Oster, M. (2013). Gehinom znaczy piekło: przeżytem getto i dziewięć obozów, Kraków: Wydawnictwo UJ.

Poradowski, S. (1983). Zagłada Żydów rzeszowskich, cz. I, „Biuletyn Żydowskiego Instytutu Historycznego", Warszawa: ŻIH - Inst. Nauk.-Badawczy.

Poradowski, S. (1997). Zagłada Żydów rzeszowskich, cz. II, „Biuletyn Żydowskiego Instytutu Historycznego". Warszawa: ŻIH - Inst. Nauk.-Badawczy.

Rączy, E. (2014). Zagłada Żydów w dystrykcie krakowskim w latach 1939-1945. Rzeszów: Uniwersytet Rzeszowski: Instytut Pamięci Narodowej - Komisja Ścigania Zbrodni przeciwko Narodowi Polskiemu.

Rączy, E. (2016). Stosunki Polsko-żydowskie w latach II wojny światowej na Rzeszowszczyźnie [w:] Żbikowski A., Polacy i Żydzi pod okupacja niemiecka 1939-1945. Studia i Materiaty. Warszawa: Instytut Pamięci Narodowej - Komisja Ścigania Zbrodni przeciwko Narodowi Polskiemu. 
Ringelblum, E. (1988). Kronika getta warszawskiego: wrzesień 1939 - styczeń 1943. Warszawa: Czytelnik.

Salsitz, N. (1971). Holokaust in Kolbuszowa, Yaari-Wald M., red., Kolbuszowa Memorial Book, New Yourk: Di fareyniḳțe (yunayțed) Kolbushoỵer.

Salton, G.L. (2014). The 23rd Psalm: A Holocaust Memoir, Madison: University of Wisconsin Press.

The United States Holocaust Memorial Museum Encyclopedia of Camps and Ghettos, 1933-1945. Vol. 2: Ghettos in German-Occupied Eastern Europe (2009), Megargee, G.P., Dean, M., Browning, Ch, red., Washington: Indiana University Press,

The Yad Vashem Encyclopedia of the Ghettos During the Holocaust. Vol. 1 (A-M): LXXVI. Abb.; Vol. 2 (N-Z), red. G. Miron. Jerusalem: Yad Vashem.

Wierzbieniec, W. (1995). Losy rzeszowskich Żydów podczas II wojny światowej $w$ relacjach światków (z Archiwum Yad Vashem w Jerozolimie). „Studia Rzeszowskie”, t. 2.

Wierzbieniec, W. (2013). Żydzi w województwie lwowskim $w$ okresie międzywojennym, Rzeszów: Wydaw. Uniwersytetu Rzeszowskiego.

Wnęk, S. (1995). Żydzi w Błażowej od XVII wieku. „Prace Historyczno-Archiwalne”, t. 3.

Wójcik, Z. (1998). Rzeszów w latach drugiej wojny światowej: 1939 - 1944 - 1945. Kraków; Rzeszów: Instytut Europejskich Studiów Społecznych: Poligrafia Wyższego Seminarium Duchownego.

Zamoyski, G. (2004). Szpital żydowski [w:] Budzyński, Z., red., Encyklopedia Rzeszowa. Rzeszów: Mitel.

DOI: $10.7862 /$ rz.2020.hss.36

The text was submitted to the editorial office: November 2019.

The text was accepted for publication: September 2020. 